\section{Ripening of Kiwifruit Exposed to Ethanol and Acetaldehyde Vapors}

\author{
F. Mencarelli and P. Savarese \\ Istituto Tecnologie Agro Alimentary, Universitá della Tuscia, Via De \\ Lellis, 01100 Viterbo, Italy
}

\author{
M.E. Saltveit, Jr. \\ Department of Vegetable Crops/Mann Laboratory, University of \\ California, Davis, CA 9.5616
}

Additional index words. Actinidia deliciosa, soluble solids concentration, titratable acidity, respiration, ethylene, firmness

Abstract. Exposure to acetaldehyde (M) vapors that produced tissue levels of $\mathbf{0 . 0 2 \%}$ AA (w/w) stimulated ripening of 'Hayward' kiwifruit (Actinidia deliciosa $\mathbf{L}$.) much more effectively than exposure to ethanol vapors that produced tissue levels of $0.18 \%$ ethanol. Tissue levels of $0.02 \%$ and $0.18 \%$ ethanol stimulated ripening, while the ripening rate of tissue with $0.04 \%$ was similar to the controls. Ethylene and $\mathrm{CO}_{2}$ production from M-treated tissues were, respectively, 23 times and $60 \%$ higher than from control tissues. AA induced a rapid softening that was localized in the core tissue and rendered the fruit unmarketable for 7 days after treatment.

A brief postharvest exposure to ethanol vapors reduced the rate of tomato fruit ripening (Saltveit and Mencarelli, 1988), possibly through its effect on membranes associated with ethylene action (Saltveit, 1989). Treatment with ethanol also reduces the astringency of Japanese persimmon (Pesis and Ben-Arie, 1984) while stimulating respiration and ethylene synthesis (Itamura, 1986; Ito, 1971). Exposure to acetaldehyde (AA) vapors promotes ripening and ethylene synthesis in pears (Janes and Frenkel, 1978) as well as color formation and a climactericlike respiratory rise in blueberry and straw-

Received for publication 17 Nov. 1990. The cost of publishing this paper was defrayed in part by the payment of page charges. Under postal regulations, this paper therefore must be hereby marked advertisement solely to indicate this fact.

\section{berry fruit (Janes et al., 1978).}

Kiwifruit are very sensitive to ethylene and their storability is inversely correlated with the concentration of ethylene in the storage atmosphere (Arpaia et al., 1980; Ito and Hashinaga, 1985). Kiwifruit are also very susceptible to mechanical injury at harvest and during shipping due to flesh softening (Gatti, 1984). Results reported in this paper show the effect of exposure to ethanol and AA vapors on the ripening and softening of kiwifruit.

'Hayward' kiwifruit were purchased from a commercial source during the harvest season; late October to the end of November 1988. Within a few hours of harvest, the fruit were sorted on the basis of fruit size and firmness. Fruit were subjectively judged to be hard when they did not deform under slight hand pressure. Fruit were separated
Table 1. Soluble solids content and titratable acidity of kiwifruit treated with ethanol and acetaldehyde vapors for $7 \mathrm{~h}$ and held at $17 \mathrm{C}$ in ethylene-free air for 13 days.

\begin{tabular}{|c|c|c|}
\hline \multirow{2}{*}{$\begin{array}{l}\text { Tissue } \\
\text { levels } \\
\text { (w/w) }\end{array}$} & \multicolumn{2}{|c|}{ Time after treatment (days) } \\
\hline & 1 & 13 \\
\hline \multicolumn{3}{|c|}{ Soluble solids content $(\%)^{z}$} \\
\hline \multicolumn{3}{|l|}{ Ethanol } \\
\hline $0.18 \%$ & 6.2 & 10.4 \\
\hline $0.04 \%$ & 6.1 & 8.7 \\
\hline $0.02 \%$ & 5.9 & 9.6 \\
\hline \multicolumn{3}{|c|}{ Acetaldehyde } \\
\hline $0.04 \%$ & 5.8 & 12.9 \\
\hline $0.02 \%$ & 5.9 & 12.8 \\
\hline Control & 6.2 & 9.3 \\
\hline LSD $5 \%$ & 0.3 & -- \\
\hline LSD $1 \%$ & $\cdots$ & 0.8 \\
\hline \multicolumn{3}{|c|}{ Titratable acidity (\% citric acid) ${ }^{\mathrm{y}}$} \\
\hline \multicolumn{3}{|l|}{ Ethanol } \\
\hline $0.18 \%$ & 2.0 & 1.3 \\
\hline $0.04 \%$ & 2.1 & 1.5 \\
\hline $0.02 \%$ & 1.9 & 1.2 \\
\hline \multicolumn{3}{|c|}{ Acetaldehyde } \\
\hline $0.04 \%$ & 2.0 & 1.6 \\
\hline $0.02 \%$ & 1.9 & 0.9 \\
\hline Control & 1.9 & 1.0 \\
\hline LSD $5 \%$ & NS & $\ldots$ \\
\hline LSD $1 \%$ & -.. & 0.18 \\
\hline
\end{tabular}

${ }^{2}$ Data are the mean of three readings from each fruit, for three fruits for each replicate, and two replicates per each of two experiments. Mean separation by LSD at $P=0.05$ or 0.01 .

${ }^{y}$ Data are the mean of readings from $10 \mathrm{~g}$ of tissue from each fruit, for three fruits for each replicate, and two replicates per each of two experiments. Mean separation by LSD at $P=0.05$ or 0.01 .

into 12 groups of 13 fruit each $(\approx 1.5 \mathrm{~kg}$ / group); two replicates for each of the six treatments (three ethanol levels, two AA levels, and a water control). Each of the 12 groups of fruit was placed in a 5-liter jar, the jar capped with a large two-hole rubber stopper, and reagent-grade absolute ethanol, $\mathrm{AA}$, or distilled water then was injected into the jar through serum stoppers in the holes in the rubber stopper as described by Saltveit 


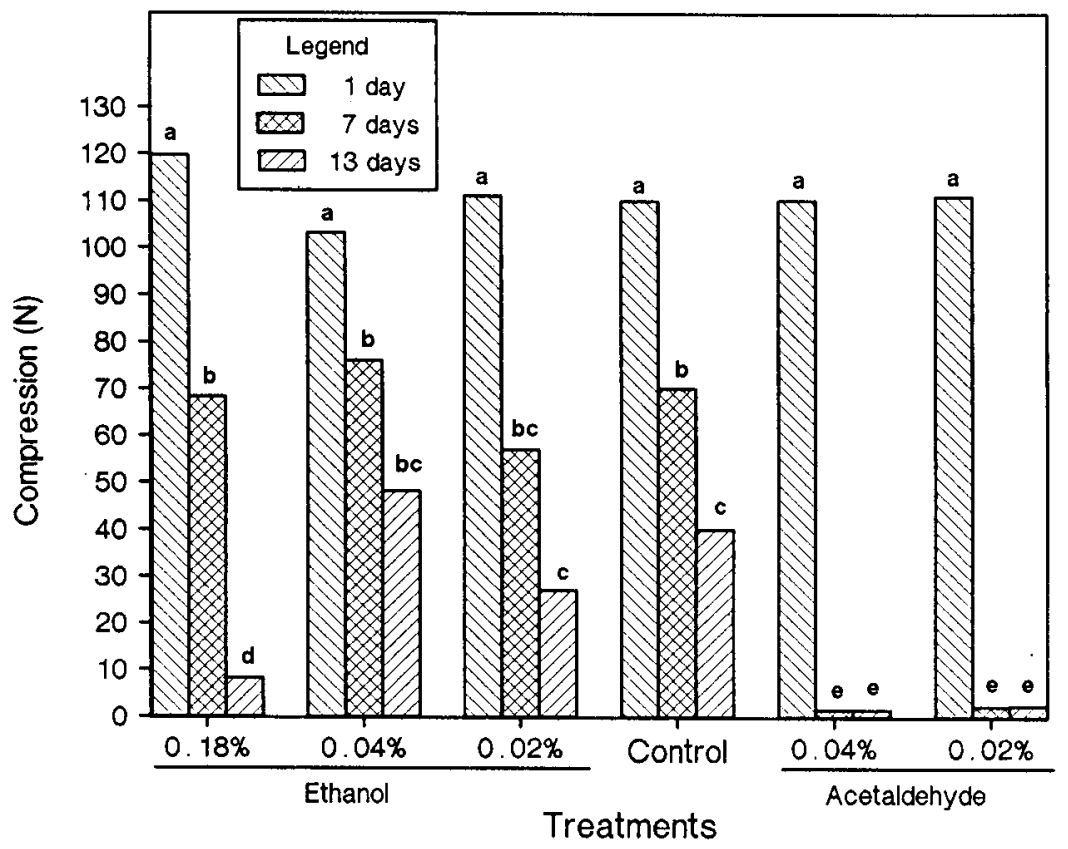

Fig. 1. Core tissue firmness of kiwifruit exposed to ethanol and acetaldehyde vapors for $7 \mathrm{~h}$ at $17 \mathrm{C}$ and held in ethylene-free air at $17 \mathrm{C}$ for 1,7 , or 13 days. Mean separation for each variable by Duncan's multiple range test, $P=0.01$.

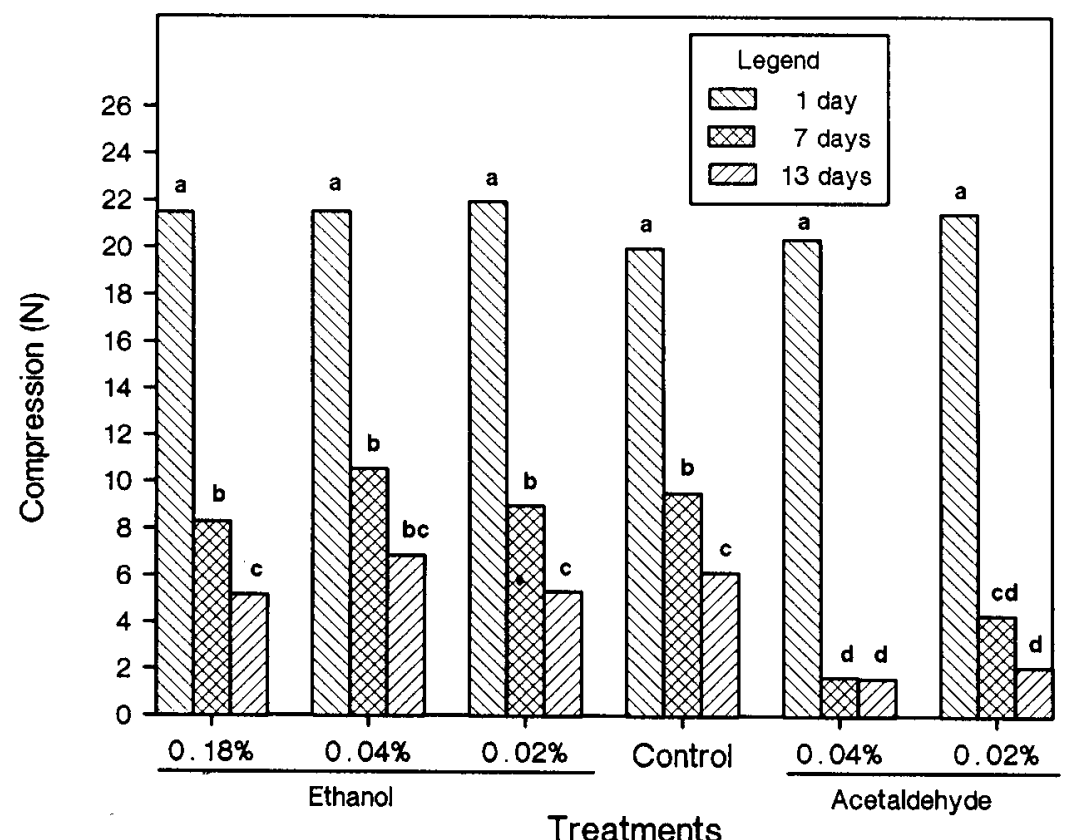

Fig. 2. Flesh firmness of kiwifruit exposed to ethanol and acetaldehyde vapors for $7 \mathrm{~h}$ at $17 \mathrm{C}$ and held in ethylene-free air at 17C for 1, 7, and 13 days. Mean separation for each variable by Duncan's multiple range test, $P=0.01$.

and Mencarelli (1988). Calculated amounts of ethanol and AA were introduced into the jars to produce concentrations of $0.02 \%$, $0.04 \%$, or $0.18 \%(\mathrm{w} / \mathrm{w})$ ethanol and $0.02 \%$ or $0.04 \%(\mathrm{w} / \mathrm{w})$ AA in the kiwifruit tissue. After holding the jars for $7 \mathrm{~h}$ at $17 \mathrm{C}$, the jars were flushed with air and the fruit were kept for 13 days in an ethylene-free atmosphere at $17 \mathrm{C}$. Less than $0.7 \% \mathrm{CO}_{2}$ had accumulated in the jars at the end of the 7-h treatment.

Fruit ripening was followed by measuring fruit firmness, soluble solids content (SSC),
Table 2. ACC content ( $\mathrm{nmol} \cdot \mathrm{g}^{-1}$ fresh weight) of kiwifruit treated with ethanol and acetaldehyde vapors for $7 \mathrm{~h}$ and held at $17 \mathrm{C}$ in ethylene. free air for 13 days. The ACC content was 0.023 $\mathrm{nmol} \cdot \mathrm{g}^{-1}$ before treatment.

\begin{tabular}{|c|c|c|}
\hline \multirow{3}{*}{$\begin{array}{l}\text { Tissue } \\
\text { levels } \\
\text { (w/w) }\end{array}$} & \multicolumn{2}{|c|}{ ACC content $\left(\mathrm{nmol} \cdot \mathrm{g}^{-1}\right)$} \\
\hline & \multicolumn{2}{|c|}{ Time after treatment (days) } \\
\hline & 1 & 13 \\
\hline \multicolumn{3}{|l|}{ Ethanol } \\
\hline $0.04 \%$ & $0.052 b^{2}$ & 0.061 \\
\hline \multicolumn{3}{|l|}{ Acetaldehyde } \\
\hline $0.04 \%$ & $0.42 \mathrm{a}$ & $3.2 \mathrm{a}$ \\
\hline Control & $0.026 \mathrm{c}$ & $0.051 \mathrm{~b}$ \\
\hline
\end{tabular}

${ }^{2}$ Data are the mean readings from each fruit, for three fruits for each replicate, and two replicates per each of two experiments. Mean separation for each variable within columns by Duncan's multiple range test, $P=0.01$.

sue to $\mathrm{pH} 8.2$ with $0.1 \mathrm{~N} \mathrm{NaOH}$ and is presented as percent citric acid. The percent SSC of the expressed juice was determined with a Galileo Abbe refractometer (Galileo SpA., Florence, Italy). Carbon dioxide concentrations were measured with an Isolcell Infrared Analyzer and $\mathrm{C}_{2} \mathrm{H}_{4}$ concentrations were measured with a Carlo Erba model Fractovap gas chromatography (Carlo Erba SpA., Milan, Italy) equipped with an 80 to 100 mesh alumina column kept at $100 \mathrm{C}$ and a flame ionization detector as described by Mencarelli and Saltveit (1988). Content of 1-amino cyclopropane-1-carboxylic acid (ACC) was evaluated according to Lizada and Yang (1979). The experiment was conducted twice with similar results.

Subjective and objective measurements failed to detect any changes in firmness between the initial and day 1 observations. After 7 days, there were no differences in core tissue firmness among the ethanol treatments and the control. After 13 days of storage, $0.02 \%$ and $0.18 \%$ ethanol had reduced core firmness, while fruit with $0.04 \%$ ethanol were as firm as the control (Fig. 1). In contrast, ethanol had no significant effect on flesh firmness after any storage period (Fig. 2). AA-treated fruit behaved differently. Within 7 days of treatment, core tissue firmness was reduced by $>90 \%$ by $0.04 \%$ and $0.02 \%$ AA (Fig. 1). These treatments also reduced flesh firmness by $\gg 80 \%$ to $90 \%$ (Fig. 2). The rapid softening produced by both AA concentrations rendered the fruit unmarketable because of excessive softness.

The ratios of core to flesh firmness after 1 day of treatment were between 5 and 6 for all samples. After 7 days, the ratios had dropped to $<1$ for both AA treatments, while the ratio increased to between 6 and 8 for the ethanol treatments and the water control. After 13 days, the ratios for all AA treatments and for the $0.18 \%$ ethanol treatment were similar and significantly lower than for the other treatments and the control, which were between 5 and 7 . These lower ratios at 13 days indicate that both AA levels and $0.18 \%$ ethanol hastened ripening. This conclusion is confirmed by the higher SSC for these treated fruit in comparison to the $0.02 \%$ and $0.04 \%$ ethanol treatments and the water control (Table 1). 


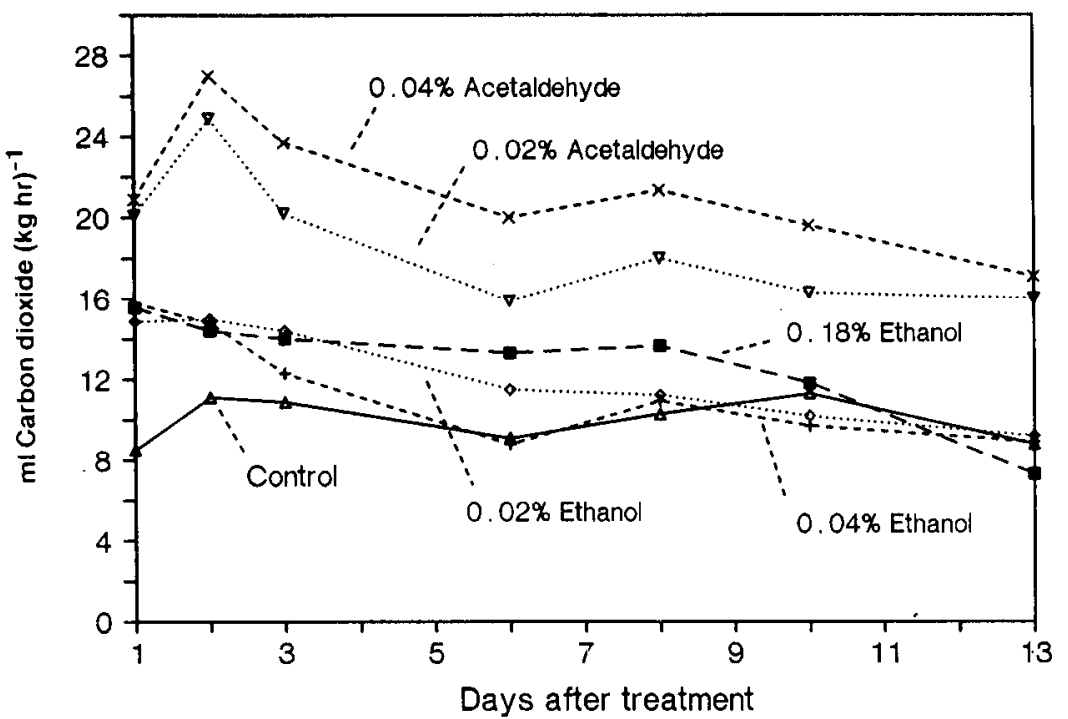

Fig. 3. Production of $\mathrm{CO}_{2}$ in $\mathrm{ml} \cdot(\mathrm{kg} \cdot \mathrm{h})^{-1}$ from kiwifruit exposed to ethanol and acetaldehyde vapors for $7 \mathrm{~h}$ at $17 \mathrm{C}$ and subsequently held in ethylene-free air at $17 \mathrm{C}$.

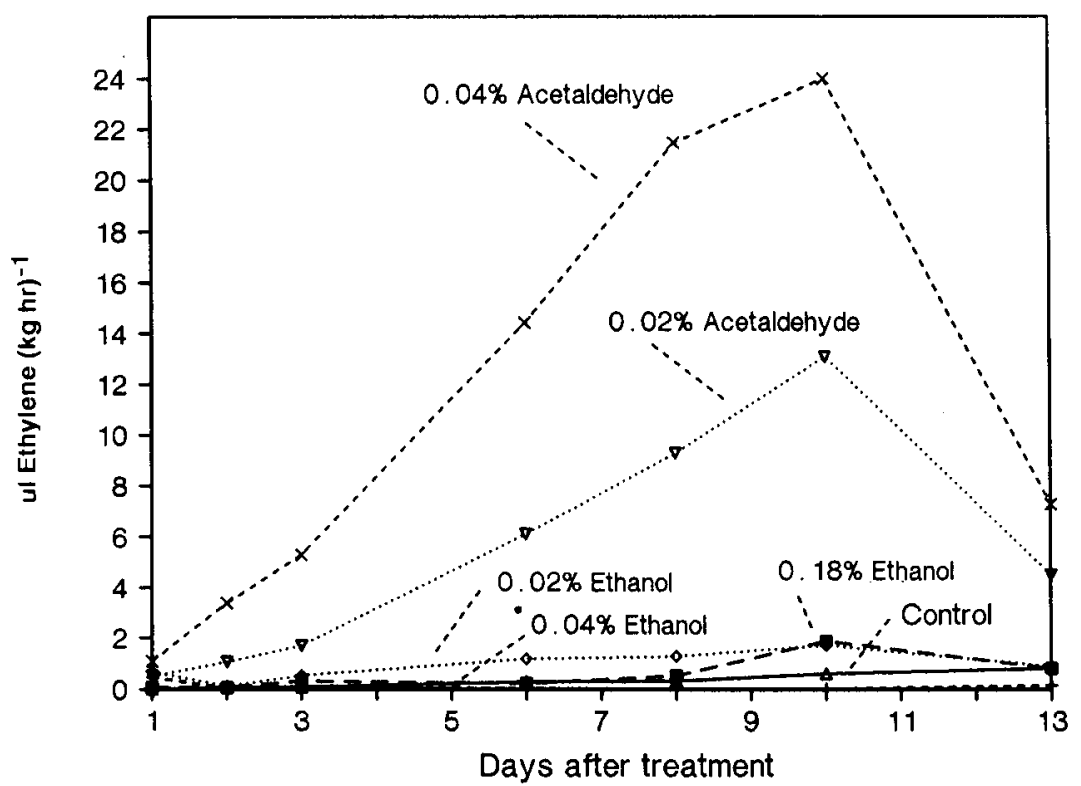

Fig. 4. Production of $\mathrm{C}_{2} \mathrm{H}_{4}$ in $\mu \mathrm{l} \cdot(\mathrm{kg} \cdot \mathrm{h})^{-1}$ from kiwifruit exposed to ethanol and acetaldehyde vapors for $7 \mathrm{~h}$ at $17 \mathrm{C}$ and subsequently held in ethylene-free air at $17 \mathrm{C}$.

Titratable acidity declined with storage for all treatments (Table 1). The decline from day 1 to day 13 ranged from an average of $50 \%$ for the control and $0.02 \%$ AA-treated tissue, to an average of $34 \%$ for the ethanoltreated tissue, to $20 \%$ for the $0.04 \%$ AA treatment. The $0.04 \%$ ethanol and the $0.04 \%$ AA treatments retained the most titratable acidity, $71 \%$ and $80 \%$, respectively. These data suggest that the metabolism of organic acids was most inhibited by the $0.04 \%$ ethanol and AA treatments, less by the remaining ethanol treatments, and not at all by $0.02 \%$ AA.

One day after treatment, $\mathrm{CO}_{2}$ production was higher from tissue exposed to ethanol or AA than from the controls, and then gradually declined (Fig. 3). AA-treated tissue had a small peak in $\mathrm{CO}_{2}$ production 2 days after treatment, and had significantly higher rates ethanol, while $\mathrm{C}_{2} \mathrm{H}_{4}$ production from tissue with $0.04 \%$ ethanol was lower than for the control.

The ACC content was measured in control fruit and fruit with tissue levels of $0.04 \%$ ethanol and $0.04 \%$ AA because they showed very different ripening behavior. Seven days after treatment, fruit with $0.04 \%$ AA had 16 times more ACC than air control fruit, while fruit with $0.04 \%$ ethanol had only twice the control level of ACC (Table 2). After 13 days of storage, the ACC content of the AAtreated tissue had increased to 63 times the air control, while the increase in ACC content of the ethanol-treated tissue was now similar to that in the controls. The ACC content of control fruit had almost doubled between 7 and 13 days of storage, but it still was much lower than in the AA-treated tissues.

An untrained, informal taste panel was unable to detect any flavor differences among the treated and control fruit after 13 days, except for the $0.02 \%$ and $0.04 \%$ AA and $0.18 \%$ ethanol treated fruit, which had a flat, insipid flavor and were too soft.

Exogenous application of AA stimulated the ripening of kiwifruit, as described with other fruits (Janes and Frenkel, 1978; Janes et al., 1978). Fruit with tissue levels of $0.04 \%$ ethanol ripened more slowly than fruit with tissue levels of $0.02 \%$ or $0.18 \%$ ethanol. The differential effect of ethanol on inhibiting ethylene action (Saltveit, 1989) and of its close metabolize, AA, on promoting ripening (Janes and Frenkel, 1978) may account for the anomalous response of ripening kiwifruit to ethanol.

\section{Literature Cited}

Arpaia, M. L., F.G. Mitchell, and G. Mayer. 1980. The effect of ethylene and high carbon dioxide on the storage of kiwifruit. HortScience 15(3):423. (Abstr.)

Gatti, R. 1984. Susceptibility of kiwifruits to mechanical injury at harvest and during storage. MS Thesis, Univ. of California, Davis.

Itamura, H. 1986. Relationship between fruit softening, respiration and ethylene production after deastringent treatment by alcohol in Japanese persimmon (Diospyros kaki Thunb var. Hiratanenaski) fruit harvested at various stages. J. Jpn. Soc. Hort. Sci. 55:89-98.

Ito, S. 1971. The persimmon, p. 281-301. In: A.C. Hulme (ed.). The biochemistry of fruits and their products. vol. 2. Academic, New York.

Ito, S. and F. Hashinaga. 1985. Effect of ethylene on the acceleration of kiwifruit ripening (English summary). Gakujutsu Hokoku Bul. Faculty Agr., Kagoshima Univ., Mar. 1985.35:49-53.

Janes, H.W. and C. Frenkel. 1978. Promotion of softening processes in pear by acetaldehyde, independent of ethylene action. J. Amer. Soc. Hort. Sci. 103:397-400.

Janes, H. W., C.K. Chin, and C. Frenkel. 1978 Respiratory upsurge in blueberries and strawberries as influenced by ethylene and acetaldehyde. Bet. Gaz. 139:50-52.

Lizada, M.C.C. and S.F. Yang. 1979. A simple and sensitive assay for 1-aminocyclopropane-1carboxilic acid. Anal. Biochem. 100:140-145.

Mencarelli, F. and M.E. Saltvcit, Jr. 1988. Ripening of mature-green. tomato fruit slices. J. Amer. Soc. Hort. Sci. 113:742-745. 
Pesis, E. and R. Ben-Arie. 1984. Involvement of acetaldehyde and ethanol accumulation during induced deastringeney of persimmon fruits. J. Food Sci. 49(3):896-899.
Saltveit, M. E., Jr. 1989. Effect of alcohols and their interaction with ethylene on the ripening of epidermal pericarp discs of tomato fruit. Plant Physiol. 90:167-174.
Saltveit, M. E., Jr. and F. Mencarelli. 1988. Inhibition of ethylene synthesis and action in ripening tomato fruit by ethanol vapors. J. Amer. Soc. Hort. Sci. 113(4):572-576. 